\title{
Omovertebral bone causing traumatic compression of the cervical spinal cord and acute neurological deficits in a patient with Sprengel's deformity and Klippel-Feil syndrome: case report
}

\author{
Michael Pompliano, MD, ${ }^{1}$ Stuart Changoor, MD, ${ }^{1}$ Samuel Mease, MD, ${ }^{1}$ Cyrus Emami, ${ }^{2}$ \\ Kumar Sinha, MD, ${ }^{1,2}$ and Ki Soo Hwang, MD ${ }^{1,2}$
}

'Department of Orthopedic Surgery, St. Joseph's University Medical Center, Paterson; and 2University Spine Center, Wayne, New Jersey

\begin{abstract}
The presence of an omovertebral bone with Sprengel's deformity and Klippel-Feil syndrome is a complex congenital anomaly that is not well understood. It most commonly manifests as cosmetic deformity, limited range of motion, and functional disability, although there are reports of the insidious development of cervical myelopathy. In this paper, the authors present the case of a 49-year-old man with acute neurological deficits after a low-energy mechanism of traumatic spinal cord compression, resulting from an impinging omovertebral bone through a traumatic laminar defect. The patient underwent resection of the omovertebral bone, laminectomy decompression of the spinal canal, and anterior stabilization. This case highlights a rarely discussed complication of undiagnosed Sprengel's deformity and its associated conditions following even low-energy traumatic mechanisms.
\end{abstract}

https://thejns.org/doi/abs/10.3171/2020.6.SPINE20304

KEYWORDS omovertebral bone; traumatic spinal cord compression; Klippel-Feil syndrome; acute neurological deficits; Sprengel's deformity; congenital

$\mathrm{K}$ LIPPEL-FeIL syndrome is a rare congenital disorder characterized by the abnormal fusion of 2 or more cervical vertebrae, resulting in a short neck, low posterior hairline, and limited neck range of motion (ROM). It is associated with many musculoskeletal abnormalities, including scoliosis, spina bifida, congenital muscular torticollis, and Sprengel's deformity. ${ }^{1}$

Sprengel's deformity is a rare congenital disorder consisting of an elevated, dysplastic scapula due to failure of scapular descent during the 9th through 12th weeks of gestation. It affects males and females equally, but the exact cause and incidence are unknown. Approximately $20 \%-25 \%$ of patients with Sprengel's deformity have an omovertebral connection (either fibrous or osseous) between the superomedial border of the scapula and the spinous process, transverse process, or the lamina of the C4-7 vertebral bodies in the cervical spine. ${ }^{2,3}$ This complex malformation results in cosmetic deformity with pain, limited ROM, and symptomatic functional disability of the affected shoulder. ${ }^{4}$

In this report, we describe the presentation and clinical course of a patient with acute neurological deficits sec- ondary to traumatic compression of the spinal cord at the level of an impinging omovertebral bone with associated laminar defects. There have been several reports of operative intervention, typically performed in the pediatric patient, for Sprengel's deformity to address issues, including decreased shoulder ROM and cervical pain. ${ }^{5}$ One report exists in the literature of a patient requiring cervical decompression for symptoms of myelopathy secondary to an omovertebral bone. ${ }^{6,7}$ To our knowledge, there are no reports of an omovertebral bone causing acute neurological deficits in the setting of trauma, especially from a lowenergy mechanism.

\section{Case Report \\ History, Physical, and Imaging Findings}

This patient was a 49-year-old Hispanic male construction worker with a past medical history of hypertension, who was brought to the emergency department as a trauma alert after a fall at work. He was walking backward and fell approximately 3 feet into a hole. In the emergency department he reported neck pain and left-sided weakness with 

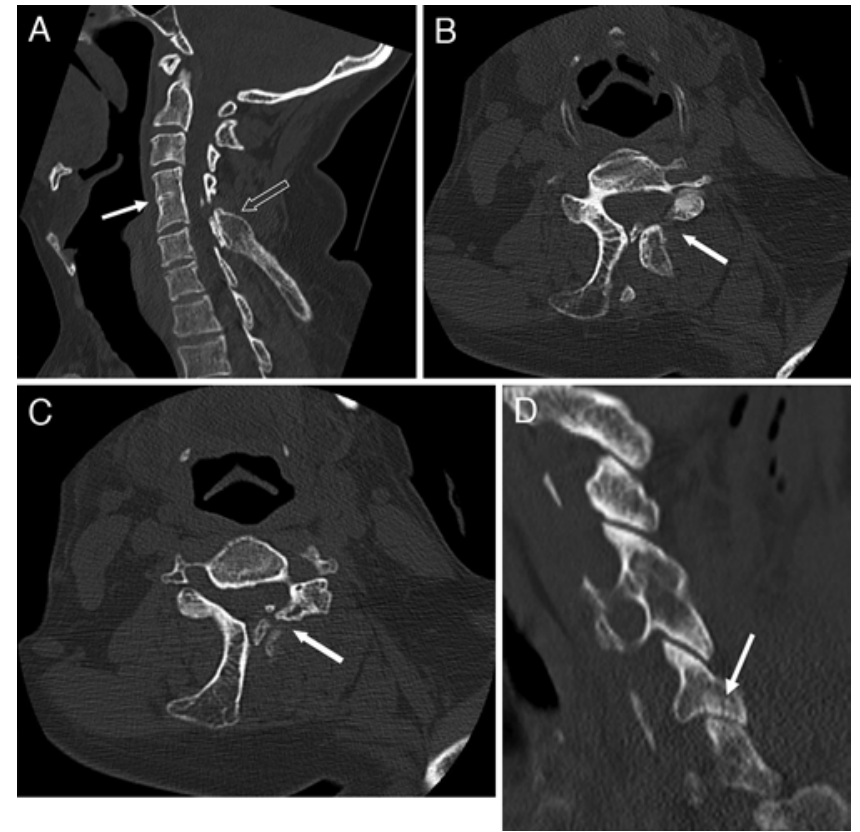

FIG. 1. Cervical spine CT scans. A: Sagittal image demonstrating congenital fusion of $\mathrm{C} 4-5$ vertebral bodies (solid arrow) with the presence of an omovertebral bone articulating with the base of the left C5 lamina (outlined arrow). B and C: Axial images demonstrating the left C5 laminar defect with comminuted bone fragments within the canal (arrows). D: Sagittal image demonstrating a nondisplaced fracture of the left C6 inferior articular process (arrow)

paresthesias. A CT scan of his head and cervical spine were performed, demonstrating congenital fusion of the cervical spine at C4-5, with left-sided Sprengel's deformity and an omovertebral bone extending from the medial border of the left scapula to the base of the left C5 lamina (Fig. 1A). There was a significant comminuted laminar defect with bone fragments within the spinal canal, as well as a nondisplaced fracture of the left C6 inferior articular process (Fig. 1B-D). Radiographs of the left shoulder again demonstrated an omovertebral bone originating at the superomedial border of the left scapula and extending to the cervical spine (Fig. 2). The orthopedic spine service was subsequently consulted.

During orthopedic evaluation, the patient complained primarily of neck pain, with left upper- and lower-extremity pain and paresthesia. He denied any known congenital abnormalities, previous neck or shoulder pain, history of similar weakness or paresthesia, gait imbalance, and bowel or bladder dysfunction. However, he did report a history of limited neck and left shoulder ROM. He exhibited tenderness to palpation over the posterior cervical spine. On neurological examination, he presented with an American Spinal Injury Association Impairment Scale (AIS) grade $\mathrm{C}$ incomplete spinal cord injury, characterized by profound left-sided deficits with $1 / 5$ motor strength in the C6-8 and L2-S1 distributions. He had decreased sensation and was hyporeflexic throughout the left upper and lower extremities. He exhibited no neurological deficits in either the right upper or lower extremities. Perianal sensation and rectal tone were intact.

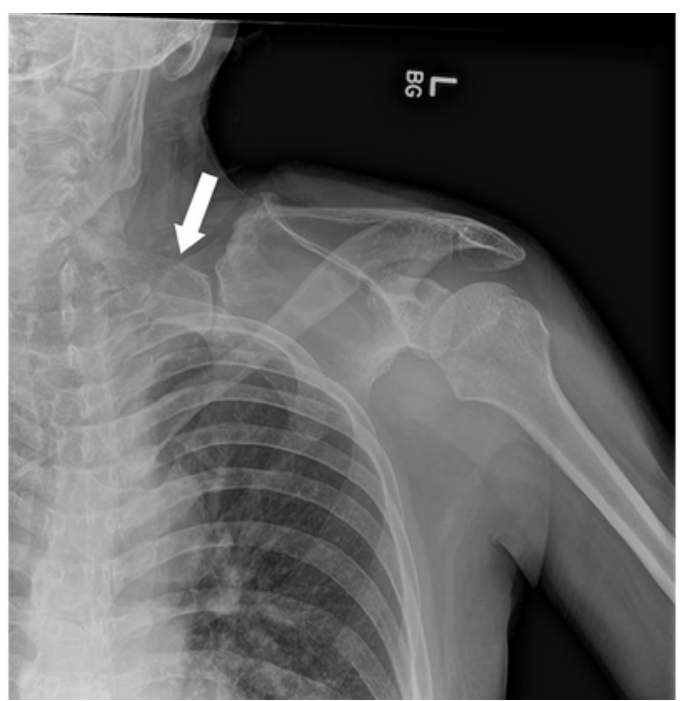

FIG. 2. Anteroposterior radiograph of the left shoulder demonstrating the omovertebral bone (arrow), originating at the superomedial border of the left scapula and extending to the cervical spine.

An MR image of the cervical spine was obtained. Bright T2 signal was appreciable within the spinal cord at the level of the laminar defect, consistent with intramedullary edema and hemorrhage. There was also evidence of edema over the posterior paraspinal elements at this level, and signal changes suggesting epidural hematoma at the level of injury both anterior and posterior to the cord (Fig. 3).

\section{Surgery and Postoperative Course}

Due to his acute neurological deficits, the patient underwent an emergency C4-6 laminectomy and decompression, with evacuation of epidural hematoma and partial resection of his omovertebral bone proximally. Motor evoked potentials obtained prior to positioning were consistent with his observed neurological deficits. During the operation, it was observed that the omovertebral bone was immediately adjacent to the spinal cord at the level of the laminar defect, with bone fragments impinging upon the dura. All bone fragments were carefully removed and the omovertebral bone was further resected.

On postoperative day 2, the patient was taken for planned, staged stabilization through an anterior approach with an anterior cervical decompression and fusion (ACDF) at C5-6 due to his congenital fusion at C4-5 and a C6 inferior articular facet fracture. Although there was mild to moderate stenosis at the C3-4 level, there were no intramedullary cord signal changes at this level, which was confirmed preoperatively by multiple musculoskeletal radiologists. In addition, the patient did not have any neurological symptoms related to this level, so it was felt that there was no clear indication to address the C3-4 level at this time. Therefore, the anterior fusion was limited to the C5-6 level to minimize surgical risk factors and preserve his current anatomy. The patient's neurological deficits were persistent in the acute postoperative period.

Since the initial injury, the patient's neurological status has significantly improved. At 2 months postoperatively, 


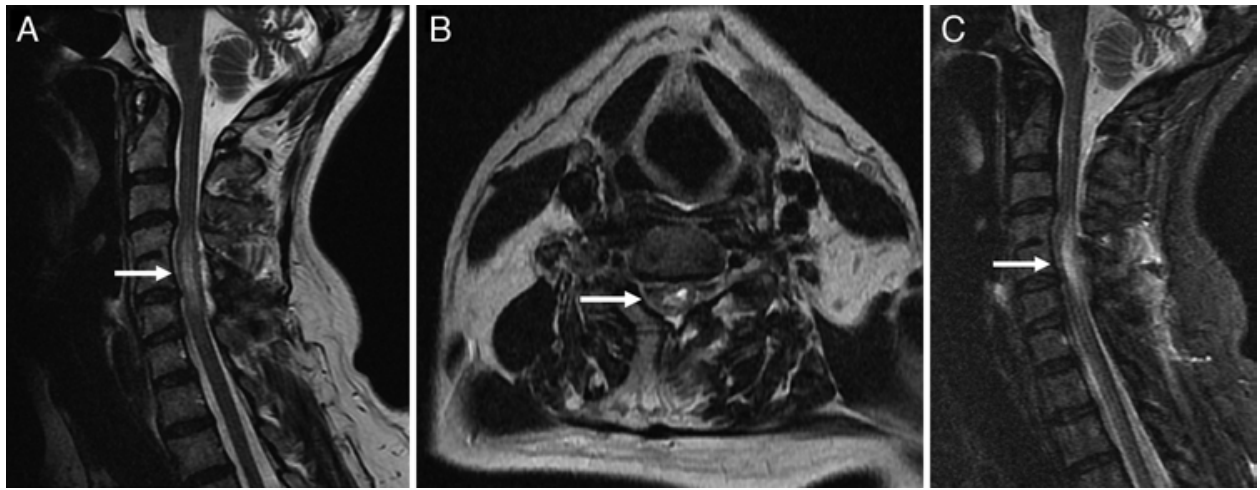

FIG. 3. Cervical spine MRI. Sagittal (A) and C5-6 axial (B) T2-weighted images, and sagittal STIR sequence (C), demonstrating intramedullary hemorrhage, epidural hematoma (arrows), and posterior paraspinal soft-tissue edema at C5-6.

he had improving left upper- and lower-extremity sensation and improving ROM with $3 / 5$ motor strength in the C6-8 distribution. At 6 months postoperatively, he had regained full sensation with his only residual deficit being minor deltoid weakness. As of his most recent 12-month follow-up visit, his neurological status continues to improve with no sensory deficits and $4+/ 5$ deltoid strength. Postoperative imaging continues to show stable alignment of implanted hardware without complications (Fig. 4).

\section{Discussion}

We present a rare case of an omovertebral bone associated with untreated Sprengel's deformity and Klippel-Feil syndrome resulting in traumatic spinal cord compression and acute neurological deficits. To the best of our knowledge, this is the first case of such a patient reported who required surgical intervention for acute neurological deficits following a traumatic mechanism. After laminectomy decompression with partial resection of the omovertebral bone and subsequent ACDF, the patient demonstrated improvement in ROM and neurological status postoperatively.

First described in 1880 by Willet and Walsham, the omovertebral bone is defined as an abnormal structure consisting of bone or cartilage that connects the superomedial border of the scapula to the posterior elements of
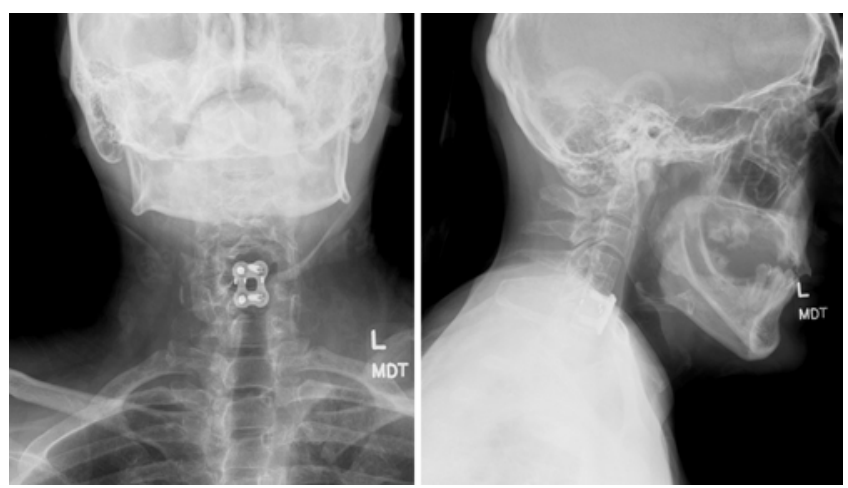

FIG. 4. Postoperative anteroposterior (left) and lateral (right) radiographs 12 months after C5-6 ACDF. the cervical spine, most commonly at the C4-7 levels. ${ }^{8,9}$ This structure is believed to arise from a remnant ossification center, as an outgrowth of the spinous process or from the scapula, but the exact origin is unknown. ${ }^{10}$ The omovertebral bone can be fused or exist as a fibrous pseudarthrosis at either end. While this can be seen in isolation, the omovertebral bone is typically associated with Sprengel's deformity, present in $30 \%-50 \%$ of these patients. ${ }^{5,10}$ Sprengel's deformity refers to an abnormally dysplastic and superior scapula caused by failure of caudal migration during the 9-12 weeks of gestation. This results in neck and shoulder pain, decreased shoulder motion, and cosmetic abnormality.,11 The combination of Sprengel's deformity and an omovertebral bone is associated with Klippel-Feil syndrome, which is distinguished by congenital fusion of 2 cervical vertebrae. ${ }^{1}$ Klippel-Feil syndrome can be seen in 16\%-27\% of patients with Sprengel's deformity. ${ }^{5}$

Sprengel's deformity is typically treated in children under the age of 8 by surgical relocation of the scapula inferiorly and usually results in improvement of cosmesis and shoulder ROM. However, excision of the omovertebral bone, particularly at adolescence and later, may improve cosmetic appearance but is not as effective at improving ROM..$^{7,11}$ Therefore, these patients are usually treated at a young age. Exclusive of the current case, there are only 4 previously published cases of adult patients undergoing surgical management for Sprengel's deformity with an omovertebral bone, none of which were due to acute trauma (Table 1).

Most recently, Gillespie et al. reported a case of a 25-year-old woman who presented with limited left shoulder ROM and progressive neck and shoulder pain. ${ }^{12}$ On physical examination, she had an elevated left shoulder with a tender and firm prominence between the left scapula and cervical spine. She underwent excision of the omovertebral bone and experienced improvement in shoulder abduction and forward flexion, increased scapulothoracic motion, and decreased pain at final follow-up.

Füllbier et al. reported a case of a 34-year-old woman who presented with chronic neck pain, progressive gait ataxia, and urinary incontinence. ${ }^{6}$ On physical examination, the patient was found to have an elevated left scapula, 
TABLE 1. Previously reported cases of omovertebral bones in adult patients

\begin{tabular}{|c|c|c|c|c|c|c|}
\hline $\begin{array}{l}\text { Authors } \\
\text { \& Year }\end{array}$ & $\begin{array}{l}\text { Age (yrs), } \\
\text { Sex }\end{array}$ & Clinical Presentation & Diagnostic Imaging Findings & Operation & Outcome & $\begin{array}{c}\text { FU } \\
\text { (mos) }\end{array}$ \\
\hline $\begin{array}{l}\text { Pompliano et } \\
\text { al., } 2020 \\
\text { (current case) }\end{array}$ & $49, \mathrm{M}$ & $\begin{array}{l}\text { Traumatic AIS grade } \\
\text { C incomplete } \\
\text { spinal cord injury } \\
\text { w/ acute It upper- } \\
\text { \& lower-extremity } \\
\text { deficits }\end{array}$ & $\begin{array}{l}\text { Radiography: omovertebral bone from } \\
\text { the superomedial border of the } \\
\text { It scapula extending to the cervi- } \\
\text { cal spine; CT: congenital fusion } \\
\text { C4-5, omovertebral bone from the It } \\
\text { scapula to the base of the C5 lamina, } \\
\text { laminar defect w/ comminution \& } \\
\text { bone fragments in the spinal canal; } \\
\text { MRI: intramedullary edema \& hemor- } \\
\text { rhage C5-6 }\end{array}$ & $\begin{array}{l}\text { C5-6 anterior } \\
\text { cervical discec- } \\
\text { tomy \& fusion, } \\
\text { partial resection } \\
\text { of omovertebral } \\
\text { bone }\end{array}$ & $\begin{array}{l}\text { Full recovery of sensation, } \\
\text { significant recovery of } \\
\text { motor strength \& func- } \\
\text { tion, w/ only residual } \\
4+/ 5 \text { It deltoid weakness }\end{array}$ & 12 \\
\hline $\begin{array}{l}\text { Gillespie et } \\
\text { al., } 2013^{12}\end{array}$ & $25, F$ & $\begin{array}{l}\text { Limited shoulder } \\
\text { ROM, progress } \\
\text { neck \& shoulder } \\
\text { pain }\end{array}$ & $\begin{array}{l}\text { Radiography \& CT: Sprengel's deformity } \\
\text { w/ omovertebral bone solidly fused to } \\
\text { the It lamina of C5-7 adjacent to ver- } \\
\text { tebral foramen; underlying posterolat- } \\
\text { eral fusion at the It C5-7 levels }\end{array}$ & $\begin{array}{l}\text { Excision of omover- } \\
\text { tebral bone }\end{array}$ & $\begin{array}{l}\text { Improvement in shoulder } \\
\text { abduction \& forward } \\
\text { flexion, increased } \\
\text { scapulothoracic motion } \\
\text { \& decreased pain }\end{array}$ & 9 \\
\hline $\begin{array}{l}\text { Füllbier et al., } \\
2010^{6}\end{array}$ & $34, F$ & $\begin{array}{l}\text { 5-mo history of } \\
\text { progressive gait } \\
\text { ataxia \& intermit- } \\
\text { tent urinary } \\
\text { incontinence }\end{array}$ & $\begin{array}{l}\text { Radiography: spina bifida from C5-T1 } \\
\text { \& vertebral body fusion for C2-3 \& } \\
\text { C6-7; CT \& MRI: omovertebral bone } \\
\text { extending from superomedial border } \\
\text { of It scapula to C6 transverse process } \\
\text { w/ constriction }\end{array}$ & $\begin{array}{l}\text { Resection of } \\
\text { omovertebral } \\
\text { bone \& } 66 \\
\text { laminectomy } \\
\text { for spinal canal } \\
\text { decompression }\end{array}$ & $\begin{array}{l}\text { Urinary incontinence } \\
\text { resolved; neck pain \& } \\
\text { motion significantly im- } \\
\text { proved, gait ataxia was } \\
\text { slightly improved }\end{array}$ & 24 \\
\hline \multirow[t]{2}{*}{$\begin{array}{l}\text { Doita et al., } \\
2000^{13}\end{array}$} & $20, F$ & $\begin{array}{l}\text { Cosmetic deformity } \\
\text { \& posterior cervi- } \\
\text { cal pain, limited } \\
\text { neck \& shoulder } \\
\text { ROM }\end{array}$ & $\begin{array}{l}\text { Radiography: omovertebral bone } \\
\text { extending from C3-4 vertebra to It } \\
\text { scapula, spina bifida at C5, congeni- } \\
\text { tal fusion C5-7; CT: omovertebral } \\
\text { bone from cervical spinous process } \\
\text { w/ pseudarthrosis w/ scapula }\end{array}$ & $\begin{array}{l}\text { Resection of } \\
\text { omovertebral } \\
\text { bone }\end{array}$ & $\begin{array}{l}\text { Limited improvement in } \\
\text { shoulder ROM (flexion } \\
120^{\circ} \text { from } 110^{\circ}, \text { abduc- } \\
\text { tion } 100^{\circ} \text { from } 95^{\circ} \text { ); } \\
\text { significantly decreased } \\
\text { cervical neck pain \& } \\
\text { cosmetic improvement }\end{array}$ & 12 \\
\hline & $26, \mathrm{~F}$ & $\begin{array}{l}\text { Lt shoulder } \\
\text { paresthesias, } \\
\text { restricted cervical } \\
\text { ROM, elevated It } \\
\text { scapula }\end{array}$ & $\begin{array}{l}\text { Radiography: omovertebral bone ex- } \\
\text { tending from C3 to It scapula, rt-sided } \\
\text { congenital scoliosis; CT: It omover- } \\
\text { tebral bone, C3 to It scapula; also, rt } \\
\text { omovertebral bone, C7 to rt scapula }\end{array}$ & $\begin{array}{l}\text { Resection of It } \\
\text { omovertebral } \\
\text { bone }\end{array}$ & $\begin{array}{l}\text { Improved It shoulder ROM } \\
\text { (flexion } 165^{\circ} \text { from } 115^{\circ}, \\
\text { abduction } 160^{\circ} \text { from } \\
\left.100^{\circ}\right) \text {, significantly } \\
\text { improved pain }\end{array}$ & 36 \\
\hline
\end{tabular}

$\mathrm{FU}=$ follow-up.

diminished cervical motion, and a bony prominence extending from the shoulder to the neck. She had decreased sensation in bilateral lower extremities as well as hyperreflexia of the left knee and ankle jerk. Imaging demonstrated an omovertebral bone attached to the C6 transverse process causing spinal stenosis and cervical myelopathy. The patient also had associated Klippel-Feil syndrome with congenital fusion of the $\mathrm{C} 2-3$ and $\mathrm{C} 6-7$ vertebrae. She underwent resection of the omovertebral bone and C6 laminectomy with improvement in neck pain and motion as well as urinary incontinence. Her gait ataxia only minimally improved at final follow-up.

Doita et al. described cases of 2 women with KlippelFeil syndrome and untreated Sprengel's deformity who underwent surgical excision of the omovertebral bone. ${ }^{13}$ While these patients both presented with cosmetic deformity, restricted shoulder motion, and pain, they had no neurological deficits. Both patients experienced improvements in pain and shoulder ROM. These cases, in addition to the current case, suggest that surgical treatment of adults with Sprengel's deformity with omovertebral bone can result in improved ROM, decreased pain, and potentially improved neurological deficits.

In conclusion, this is a rare case of a patient with fracture of an omovertebral bone associated with Sprengel's deformity and Klippel-Feil syndrome that resulted in traumatic spinal cord compression and acute neurological deficits. He was treated with C4-6 laminectomy decompression, partial resection of the omovertebral bone, and anterior fusion for additional stability due to an adjacent facet fracture. While there has been 1 previous case of an adult patient with an omovertebral bone causing chronic myelopathy, to our knowledge this is the first case in which an omovertebral bone resulted in acute neurological deficits in the trauma setting. This case is especially interesting due to the low-energy mechanism of injury, which highlights that the potential morbidity related to Sprengel's deformity and an omovertebral bone may not be limited to cosmetic deformity, limited ROM, and symptomatic functional deficits. Furthermore, the typical resection may 
not be sufficient to treat traumatic neurological deficits in an acute setting. While it is unclear if treatment of this deformity as a child would have prevented these deficits and obviate the need for surgery, resection of this bone is typically performed at a young age. Therefore, surgeons should have a high index of suspicion in pediatric patients with limited shoulder abduction and restricted cervical motion, and consider the future implications of an untreated omovertebral bone.

\section{References}

1. Hensinger RN, Lang JE, MacEwen GD. Klippel-Feil syndrome; a constellation of associated anomalies. J Bone Joint Surg Am. 1974;56(6):1246-1253.

2. Cavendish ME. Congenital elevation of the scapula. $J$ Bone Joint Surg Br. 1972;54(3):395-408.

3. Kafadar C, Saglam M, Sonmez G, Mutlu H. Omovertebral bone associated with Sprengel deformity presented with chronic cervical pain. Spine J. 2016;16(2):e43.

4. Patel K, Evans H, Sommaruga S, et al. Characteristics and management of pain in patients with Klippel-Feil syndrome: analysis of a global patient-reported registry. J Neurosurg Spine. 2019;32(4):578-583.

5. Harvey EJ, Bernstein M, Desy NM, et al. Sprengel deformity: pathogenesis and management. J Am Acad Orthop Surg. 2012;20(3):177-186.

6. Füllbier L, Tanner P, Henkes H, Hopf NJ. Omovertebral bone associated with Sprengel deformity and Klippel-Feil syndrome leading to cervical myelopathy. J Neurosurg Spine. 2010;13(2):224-228.

7. Farsetti P, Weinstein SL, Caterini R, et al. Sprengel's deformity: long-term follow-up study of 22 cases. J Pediatr Orthop B. 2003;12(3):202-210.

8. Willett A, Walsham WJ. A second case of malformation of the left shoulder-girdle; removal of the abnormal portion of bone; with remarks on the probable nature of the deformity. Med Chir Trans. 1883;66:145-158.3.

9. Willett A, Walsham WJ. An account of the dissection of the parts removed after death from the body of a woman the subject of congenital malformation of the spinal column, bony thorax, and left scapular arch; with remarks on the probable nature of the defects in development producing the deformities. Med Chir Trans. 1880;63:257-302.3.
10. Schultz GD, Phillips RB. Omovertebral bone. J Manipulative Physiol Ther. 1989;12(1):50-53.

11. Leibovic SJ, Ehrlich MG, Zaleske DJ. Sprengel deformity. $J$ Bone Joint Surg Am. 1990;72(2):192-197.

12. Gillespie B, Shaw BA, Waters P. Surgical excision of an omovertebral bone in an adult with untreated Sprengel deformity: a case report. JBJS Case Connect. 2013;3(4):1-6.

13. Doita M, Iio H, Mizuno K. Surgical management of Sprengel's deformity in adults. A report of two cases. Clin Orthop Relat Res. 2000;(371):119-124.

\section{Disclosures}

The authors report no conflict of interest concerning the materials or methods used in this study or the findings specified in this paper.

\section{Author Contributions}

Conception and design: Changoor, Pompliano, Sinha, Hwang. Acquisition of data: Pompliano, Mease, Emami. Analysis and interpretation of data: Emami, Sinha, Hwang. Drafting the article: Changoor, Pompliano, Mease, Emami. Critically revising the article: all authors. Reviewed submitted version of manuscript: all authors. Study supervision: Sinha, Hwang.

\section{Correspondence}

Stuart Changoor: University Spine Center, Wayne, NJ. stuartchangoor@gmail.com. 